\title{
In-vitro Testing of Antioxidant, Anti-Parasite Activities, Cytotoxicity, and Chemical Evaluation of Abutilon Pannosum and Cassia Occidentalis Ethanolic Extracts
}

\begin{abstract}
Ahmed A. Elshikh ${ }^{1,2^{*}}$, Mawahib E. M. EINour ${ }^{1}$, Hatil H. Elkamali ${ }^{3}$ and Ahmed S. Kabbashi ${ }^{2}$

${ }^{1}$ Department of Biology and Biotechnology, Faculty of Science and Technology, Alneelain University, Khartoum, Sudan.

${ }^{2}$ Department of Microbiology, Faculty of Pure and Applied Sciences, International University of Africa, Khartoum, Sudan.

${ }^{3}$ Department of Botany, Faculty of Science and Technology, Omdurman Islamic University, Omdurman, Sudan.

Authors' contributions

This work was carried out in collaboration among all authors. Authors AAE and ASK conducted the experiments and wrote the manuscript. Authors MEME and HHE reviewed the manuscript and supervised the experiments inside the laboratory. All authors read and approved the final manuscript.
\end{abstract}

Article Information

DOI: $10.9734 / A R R B / 2021 / v 36 i 930431$

Editor(s):

(1) Dr. Viduranga Y. Waisundara, Australian College of Business \& Technology, Sri Lanka.

(2) Dr. Paola Angelini, University of Perugia, Italy. Reviewers:

(1) Maii Moustafa Nabieh, Tanta University, Egypt.

(2) Preetha Devaraj, SRM University, India.

(3) Smriti Roy, Arka Jain University, India. (4) Ahmed Kareem Obaid, Al-Zahrawi University College, Iraq. Complete Peer review History: https://www.sdiarticle4.com/review-history/61295

Original Research Article

Received 16 July 2020

Accepted 26 September 2020

Published 01 October 2021

\section{ABSTRACT}

Aims: The aim of this study to detect Anti-giardia, antioxidant activities, cytotoxicity and evaluated the chemical constituent of ethanolic extracts of Abutilon pannosum and Cassia occidentalis.

Study Design: Various standard methods were used to detect of bioactivity for ethanolic extracts of plants used in this study.

Place and Duration of Study: This study was conducted in the laboratories of microbiology and 
parasitology and chemistry, the International University of Africa, Khartoum, Sudan, during May 2019.

Methodology: The ethanolic extract of Abutilon pannosum and Cassia occidentalis was used as an anti-giardia and anti-oxidant in-vitro, and toxicity tests were performed using brine shrimp and MTT assay. Also, the compounds of the plants used were detected by the GCMS apparatus.

Results: The ethanolic extracts of Abutilon pannosum showed high Anti-giardia activity (79\%) in concentration (500 ppm) after 72 hours, whereas the activity of Cassia occidentalis extract showed $(61 \%)$. The highest antioxidant activity of ethanolic extract of Cassia occidentalis was $(68.7 \%)$, while it was weak in Abutilon pannosum ethanolic extract (45\%) by using 2,2-diphenyl-1picrylhydrazyl (DPPH) assay. The results of cytotoxicity revealed that the ethanolic extracts are highly toxic to brine shrimp, but are not toxic to normal cell line (MTT). Chromatographic analysis using gas chromatography-mass spectroscopy (GCMS) showed good separation of compounds. GCMS detected 22 and14 important compounds in Abutilon pannosum and Cassia occidentalis extracts respectively. The common compound in both plant extracts is $\mathrm{n}$-Hexadecanoic acid. This acid was reported as an antioxidant.

Conclusion: This study revealed that the biological activities of Abutilon pannosum extracts showed high activities of Anti-giardia and antioxidants. Non-cytotoxic in the normal cell line was shown. Cassia occidentalis showed high activity of Anti-giardia and weak activity antioxidant.

Keywords: In-vitro; antioxidant; anti-parasite; cytotoxicity; abutilon pannosum; cassia occidentalis.

\section{INTRODUCTION}

Traditional medicine is still used as the primary health care system for up to $80 \%$ of the world population, most of them are in developing countries. This popularity of traditional medicine is due to the better cultural acceptability, compatibility, and lesser side effects [1]. The frequent use of medicinal plants for the treatment of different diseases has encouraged several researchers to study their biological activities. Additionally, natural products can contribute to the discovery of novel antimicrobial and antioxidant components. Several pharmaceutical studies have demonstrated the antibacterial, antimalarial, antitrypanosomal, and antioxidant activities of Sudanese medicinal plants [2]. The use of plant and its products has a long history that began with folk medicine and through the years has been incorporated into traditional and allopathic medicine. Since antiquity, many plant species reported having pharmacological properties as they are known to possess various secondary metabolites like glycosides, saponins, flavonoids, steroids, tannins, alkaloids, tirpenes which is, therefore, should be utilized to combat the disease-causing pathogens [3]. Abutilon pannosum is one of the valuable medicinal plant burns of Malvaceae is tomentose under shrub widely distributed in India, North Africa, Asia, and Australia, and bears spherical fruits having about 25 carpels, each of which covers hairy plant widely distributed from tropical Africa to Australia through Asia. It grows to a height of $2 \mathrm{~m}$ and bears small, ovoid fruits, which contain tasteless seeds. It leaves have good medicinal activity for example antibacterial, antioxidant, antifungal [4]. Cassia occidentalis $L$ belongs to the family Caesalpiniaceae. It is a plant with huge medicinal importance. Leaves of $C$. occidentalis plant have ethnomedicinal importance like a paste of leaves is externally applied on healing wounds, sores, itch, cutaneous diseases, bone fracture, fever, ringworm, skin diseases, and throat infection. Previous pharmacological investigations showed that C. occidentalis leaf extracts have antibacterial, antimalarial, antimutagenic, antimutagenic, antiplasmodial, anticarcinogenic, and hepatoprotective activity [5]. This study aimed to investigate in vitro antibacterial, antiparasite, antioxidant activities and cytotoxicity and chemical compounds of crude extracts for Abutilon pannosum and Cassia occidentalis.

\section{MATERIALS AND METHODS}

\subsection{Plant Materials}

The Whole part of Abutilon pannosum and Cassia occidentalis were collected from Khartoum University felid. The plant was identified and authenticated by Hamza Taj-Elsir in Herbarium of Botany Department, Faculty of Agriculture, Khartoum University. All plant parts were air-dried, under the shadow with good ventilation and then ground finely in a mill until their uses for extracts preparation.

\subsection{Preparation of Crude Extracts}

100 grams of both plant samples extracted with $80 \%$ methanol by soaking for 18 hours using a shaker (Stuart scientific, flash shaker, S F 1, 
U K). The extracts were filtered and evaporated using a rotary evaporator (Buchi, 461, Switzerland) at $40^{\circ} \mathrm{C}$.

\subsection{Anti-Giardia Activity}

\subsubsection{Parasite isolate}

Giardia lamblia used in the experiment was taken from patients of Ibrahim Malik Hospital (Khartoum). All taken samples were examined by wet mount preparation; the positive samples were transported to the laboratory in nutrient broth medium. Trophozoites of E. histolytica and Giardia lamblia were maintained in RPMI 1640 medium containing $5 \%$ bovine serum at $37 \pm$ $1^{\circ} \mathrm{C}$. The trophozoites were maintained for the assays and were employed in the log phase of growth.

\subsubsection{Inoculums}

E. histolytica and Giardia lamblia was inoculated in the RPMI 1640 medium and incubated at $37 \pm$ $1^{\circ} \mathrm{C}$ for $48 \mathrm{~h}$. parasites were counted under the microscope by the hemocytometer chamber.

\subsubsection{In Vitro susceptibility assays}

In vitro susceptibility assays used the sub-culture method of Cedillo-Rivera et al., [6] which is being described as a highly stringent and sensitive method for assessing the antiprotozoal effects (gold standard) particularly in E. histolytica, Giardia intestinalis and Trichomonas vaginalis Argüello-García et al., [7]. $5 \mathrm{mg}$ from each extract and compound was dissolved in $50 \mu \mathrm{l}$ of dimethyl sulfoxide (DMSO) at Eppendorf tube containing $950 \mu \mathrm{l}$ D. W to reach the concentration of $5 \mathrm{mg} / \mathrm{ml}$ (5000 ppm). The concentrates were stored at $-20^{\circ} \mathrm{C}$ for further analysis. A sterile 96-well microtitre plate was used for different plant extracts, positive control and negative control. Three columns of a microtitre plate wells [ 8 columns $(C) \times 12$ rows $(R)$ ] were chosen for each extract, $40 \mu \mathrm{l}$ ) of an extract solution $(5 \mathrm{mg} / \mathrm{ml})$ were added to the first column wells C-1: On the other hand, $20 \mu \mathrm{l}$ of complete RPMI medium were added to the other wells of the second column and third column (C2 and $\mathrm{C}-3$ ). Serial dilutions of the extract were obtained by taking $20 \mu \mathrm{l}$ of extract to the second column wells and taking $20 \mu \mathrm{l}$ out of the complete solution in C2 wells to C-3 wells and discarding $20 \mu \mathrm{l}$ from the total solution of C-3 to the remaining $20 \mu \mathrm{l}$ serial solutions in the successive columns. $80 \mu \mathrm{l}$ of culture medium was complemented with the parasite and added to all wells. The final volume in the wells was 100 $\mu l$. In each test

$$
\begin{aligned}
& \text { Mortality of parasites }(\%)= \\
& \text { (Negative control }- \text { Tested sample with extract)/ } \\
& \text { (Negative control) } \times 100 \% \text {. }
\end{aligned}
$$

Only $100 \%$ inhibition of the parasite was considered when there was no motile parasite observed.

\subsection{Antioxidant Activity}

\subsubsection{DPPH radical scavenging assay}

The DPPH free radical scavenging activity Principle: The antioxidant activity was measured in terms of hydrogen donating or radical scavenging ability using the stable radical DPPH. Experiments were carried out according to using the method of Eltayeb et al. [8], with slight modification. Active samples can reduce the stable radical DPPH to the yellow-colored diphenyl- picrylhydrazine.

\subsubsection{Assay}

Test samples were allowed to react with 2.2 di (4tretoctylphenyl)-1-picrylhydrazyl stable free radical (DPPH) for half an hour at 37oc in 96wells plate. The concentration of DPPH was kept at $(300 \mu \mathrm{M})$. The test sample was dissolved in DMSO while DPPH was prepared in ethanol. After incubation, a decrease in absorbance was measured at $517 \mathrm{~nm}$ using multiplate reader spectrophotometer. The percentage of radical scavenging activity of the sample was determined in comparison with a DMSO treated control. All tests were conducted in triplicate.

$D P P H$ radical scavenging $(\%)=100-\{(A c-$ At) $/$ Ac $\} \times 100$

Where $A t=$ Absorbance value of test compound; $A c=$ Absorbance value of the control.

\subsection{In-Vitro Cytotoxicity}

\subsubsection{Cytotoxicity screening by brine shrimp}

\subsubsection{Storage of artemia salina eggs}

Eggs of Artemia salina were stored at low temperatures $\left(4^{\circ} \mathrm{C}\right)$, they will remain viable for many years. 


\subsubsection{Hatching shrimp}

Brine shrimp eggs, Artemia salina was hatched in artificial seawater prepared by dissolving $38 \mathrm{~g}$ of sea salt in one liter of distilled water. After 24-72h incubation at room temperature $\left(37^{\circ} \mathrm{C}\right)$, the larvae were attracted to one side of the vessel with a light source and then collected with a pipette. Larvae were separated from eggs by aliquoting them three times in small beakers containing artificial seawater.

\subsubsection{Brine shrimp assay}

Bioactivity of the extract was monitored by the brine shrimp lethality test [9]. Brine shrimp lethality bioassay was carried out to investigate the cytotoxicity of plant extracts. $50 \mathrm{mg}$ of Artemia salina (Leach) eggs were added to a hatching chamber containing artificial Seawater $(75 \mathrm{ml})$. The hatching chamber was kept under an inflorescent bulb for $48 \mathrm{~h}$ for the eggs to hatch into shrimp larvae. $20 \mathrm{mg}$ of test extracts of the various plant species were separately dissolved in $2 \mathrm{ml}$ of methanol, then 500,50 , and $5 \mu \mathrm{l}$ of each solution were transferred into vials corresponding to 1000,100 , and $10 \mu \mathrm{g} / \mathrm{ml}$, respectively. Each dosage was tested in triplicate. 10 larvae of $A$. salina Leach (taken $48-72 \mathrm{~h}$ after the initiation of hatching) were added to each vial (Fig. 4). The final volume of solution in each vial was adjusted to $5 \mathrm{ml}$ with Seawater immediately after adding the shrimps. One drop of dimethyl sulphoxide (DMSO) was added to the test and control vials before adding the shrimps to enhance the solubility of test materials. LD 50 values were determined at $95 \%$ confidence intervals by analyzing the data on a computer loaded with a "Finney Programme." The concentration at which it could kill $50 \%$ larvae $\left(L_{50}\right)$ was determined. $\mathrm{LD}_{50}$ values below $200 \mathrm{ppm}$ are generally considered as significant according to Oladimeji et al. [10].

\subsubsection{Cytotoxicity screening by micro-culture- tetrazolium MTT-assay}

Micro-culture-tetrazolium MTT-assay was utilized to evaluate the cytotoxicity of plants. This colorimetric assay is based on the capacity of mitochondria-succinate dehydrogenase enzymes in living cells to reduce the yellow water-soluble substrate 3- (4, 5-dimethyl thiazol-2-yl)-2, 5diphenyltetrazolium bromide (MTT) into an insoluble, blue colored-formazan, a product measured spectrophotometrically. Since the reduction of MTT can only occur in metabolically active cells, the level of activity is a measure of the viability of the cells [11].

\subsubsection{Cell Line and culture medium}

Vero cell line (Normal cell line) cells were cultured in a culturing flask containing a complete medium consisting of $10 \%$ fetal bovine serum and $90 \%$ minimal essential medium (MEM) and then incubated at $37^{\circ} \mathrm{C}$. The cells were subcultured twice a week.

\subsubsection{Cell counting}

Cells were counted using the improved Neubauer chamber. The coverslip and chamber were cleaned with detergent, rinsed thoroughly with distilled water and swapped with $70 \%$ ethanol, then dried. An aliquot of cell suspension was mixed with an equal volume of $0.4 \%$ trypan blue in a small tube. The chamber was charged with the cell suspension. After cells had settled, the chamber was placed under a light microscope. Using $40 \mathrm{X}$ objective, cells in the 4 large corner squares (each containing 16 small squares) were counted. The following formula was used for calculating the cells:

Number of cells counted X Dilution factor X $10^{4}($ Cells $/ \mathrm{ml})$.

\subsubsection{Assay}

Serial dilutions of extract were prepared in a 96 well flat bottomed plate (Nalge Nunc, Inter.). The outer walls of the plate were filled with $250 \mu$ of in-complete culture medium except for the last row 6 middle wells $(B-G)$, which were used for the negative control receiving $50 \mu \mathrm{l}$ of culture medium and $2 \mu \mathrm{l}$ of sterile $0.5 \%$ Triton X. 50 $\mu \mathrm{l} /$ wells complete culture medium (CCM) were added and $30 \mu \mathrm{l}$ more was added to second column wells $(B-G)$ that were used as first extract dilution wells. To the first dilution wells in the row, $500 \mu \mathrm{g}$ of $\mathrm{c}$ suspension extract were added to the $80 \mu \mathrm{l}$. extract were then serially diluted by two-fold dilution from well B3 till B11 by transferring $250 \mu \mathrm{l}$ to the next well after proper mixing. From the last dilution wells (B-11), $50 \mu \mathrm{l}$ were discarded. Each compound was tested in triplicate. Cell suspension is a complete culture medium containing $2.5 \times 10^{5} / \mathrm{ml}$ was properly mixed, and $150 \mu \mathrm{l}$ of it were transferred into each well of the plate. The plate was covered 
and placed in a $5 \% \mathrm{CO}_{2}$ incubator at $37^{\circ} \mathrm{C}$ for three-five days (72 hours-120 hours). On the third/ fifth day, the supernatant was removed from each well without detaching cells. MTT (3- (4,5-Dimethylthiazol-2-yl)-2,5diphenyltetrazolium bromide, a yellow tetrazole) stock $(5 \mathrm{mg} / \mathrm{ml})$ was prepared earlier in $100 \mathrm{ml}$ PBS (phosphate buffer saline). MTT suspension was vortexed and kept on a magnetic stirrer until all MTT dissolved. The clear suspension was filter sterilized with $0.2 \mu$ Millipore filter and stored at $4^{\circ} \mathrm{C}$ or -20 until use. MTT was diluted $(1: 3.5)$ in a culture medium and brought to room temperature. To each well of the 96 well plates, $50 \mu \mathrm{l}$ of diluted MTT were added. The plate was incubated further at $37^{\circ} \mathrm{C}$ for 2 to 3 hours in $\mathrm{CO}_{2}$ incubator. MTT was removed carefully without detaching cells, and $200 \mu \mathrm{l}$ of DMSO was added to each well. The plate was agitated at room temperature for 15 minutes then read at $540 \mathrm{~nm}$ using microplate reader. The percentage growth inhibition was calculated using the formula below:

$$
\% \text { cell inhibition }=100-\{(A c-A t) / A c\} \times 100
$$

Where, At $=$ Absorbance value of test compound; $A c=$ Absorbance value of the control.

\subsection{Gas Chromatography- Mass Spectrometry (GC-MS) Analysis}

GC-MS technique was used in this study to identify the phyto-components present in the most active fractions. The tested extracts were analyzed by GC-MS using Shimadzu Mass Spectrometer-2010 series. $1 \mu \mathrm{L}$ of the sample was injected in GC-MS equipped with a split injector. The MS was operated in the electron ionization (EI) mode $(70 \mathrm{eV})$. Helium was employed as the carrier gas and its flow rate was adjusted to $1.2 \mathrm{~mL} / \mathrm{min}$. The analytical column connected to the system was an Rtx- 5 capillary column (length- $30 \mathrm{~m} \times 0.25 \mathrm{~mm}$ i.d., $0.25 \mu \mathrm{m}$ film thickness). The column head pressure was adjusted to $93.9 \mathrm{kPa}$. Column temperature programmed from $110^{\circ} \mathrm{C}(7 \mathrm{~min})$ to $200^{\circ} \mathrm{C}$ at $10^{\circ} \mathrm{C} / \mathrm{min}$ and from $200-280^{\circ} \mathrm{C}$ at $5^{\circ} \mathrm{C} / \mathrm{min}$ withholds time 0 and $9 \mathrm{~min}$ respectively. A solvent delay of $4.50 \mathrm{~min}$ was selected. The injector temperature was set at $250^{\circ} \mathrm{C}$. The GCMS interface was maintained at $280^{\circ} \mathrm{C}$. The MS was operated in the ACQ mode scanning from $\mathrm{m} / \mathrm{z} 40$ to 550.0 . In the full scan mode, El mass spectra in the range of $40-550(\mathrm{~m} / \mathrm{z})$ were recorded at an electron energy of 70 eves. Compounds were identified by comparing mass spectra with the library of the National Institute of Standard and Technology (NIST), USA/Wiley.

\subsection{Statistical Analysis}

All data were presented as means \pm S.D. Statistical analysis for all the assays results was done using Microsoft Excel program (2010).

\section{RESULTS AND DISCUSSION}

\subsection{Antigiardial Activity}

The anti-giardia potential of the ethanolic extract of different parts of candidate plants extracted by ethanol, with different concentrations $(500,250$ and $125 \mathrm{ppm}$ ) and Metronidazole (the reference control) with concentration $(312.5 \mu \mathrm{g} / \mathrm{ml})$ was investigated against Giardia lamblia trophozoites in vitro. Ethanolic extract of $A$. pannosum showed $(79 \%, 70 \%)$ inhibition at a concentration $500 \mu \mathrm{g} / \mathrm{ml}$ after 72 and $48 \mathrm{~h}$; this was compared with Metronidazole which gave $86 \%$ inhibition at concentration $312.5 \mu \mathrm{g} / \mathrm{ml}$ at the same time against Giardia lamblia (Fig. 1). $A$. pannosum showed with an inhibition concentrations (IC) more than $99.4 \mu \mathrm{g} / \mathrm{ml}$ after three days and gave an IC50 after three days (Fig. 2). C. occidentalis crude extract showed $(61 \%, 60)$ inhibition at a concentration $500 \mu \mathrm{g} / \mathrm{ml}$ after 72 and 48h; this was compared with Metronidazole which gave $86 \%$ inhibition at concentration $312.5 \mu \mathrm{g} / \mathrm{ml}$ at the same time against G. lamblia (Fig. 3). Also crude extract showed with an inhibition concentration (IC) more than $240 \mu \mathrm{g} / \mathrm{ml}$ after three days and gave an IC50 after three days (Fig. 4). Protozoal diseases constitute major health problems worldwide, particularly in tropical developing countries. Among the protozoal parasites, Giardia lamblia and Entamoeba histolytica have the highest incidence of diarrheal diseases in developing countries. Chemotherapy is the first choice for the treatment of protozoal diseases; however, it has proven side effects. Therefore, there is a need for safe and effective treatment alternatives including plants as one of the readily available alternatives for the control and prevention of amoebiasis and giardiasis [12]. 


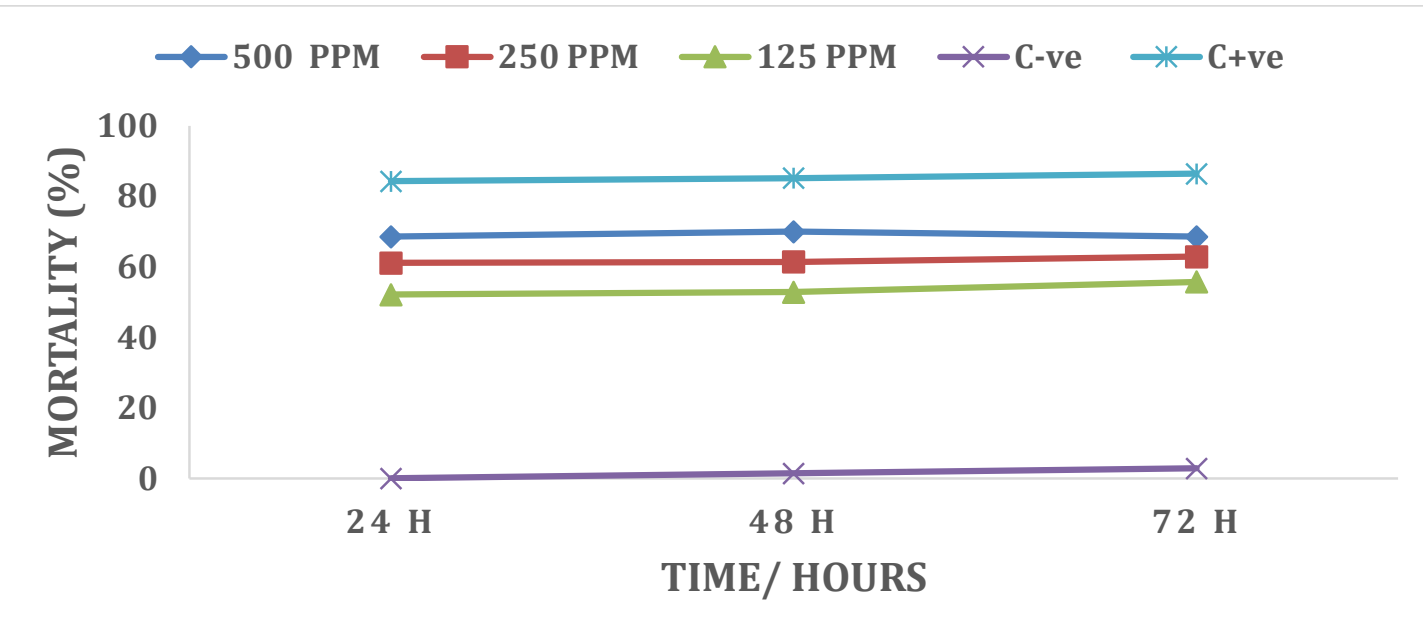

Fig. 1. In vitro activity of Abutilon pannosum ethanol extract against G. lamblia

8000.0

7000.0

6000.0

5000.0

4000.0

3000.0

2000.0

1000.0

0.0

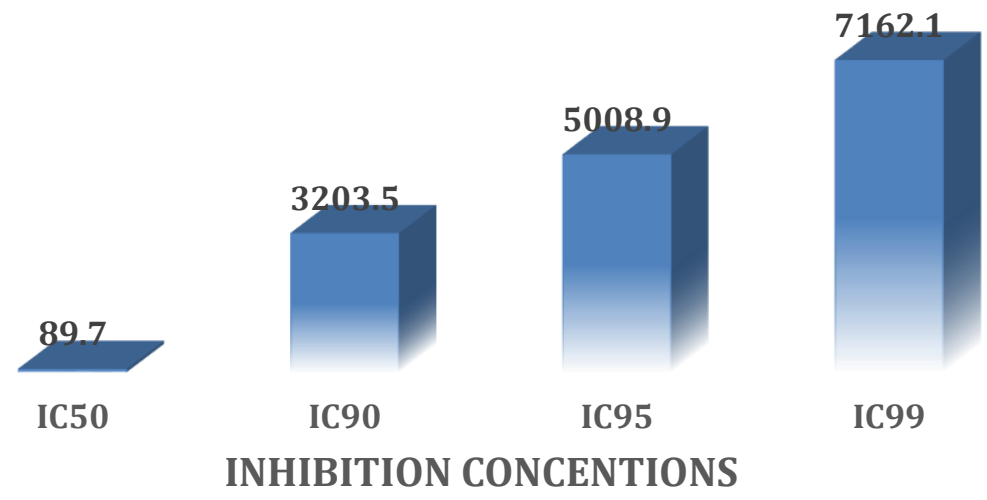

INHIBITION CONCENTIONS

Fig. 2. Inhibition concentration (IC) Abutilon pannosum ethanol extract against G. lamblia

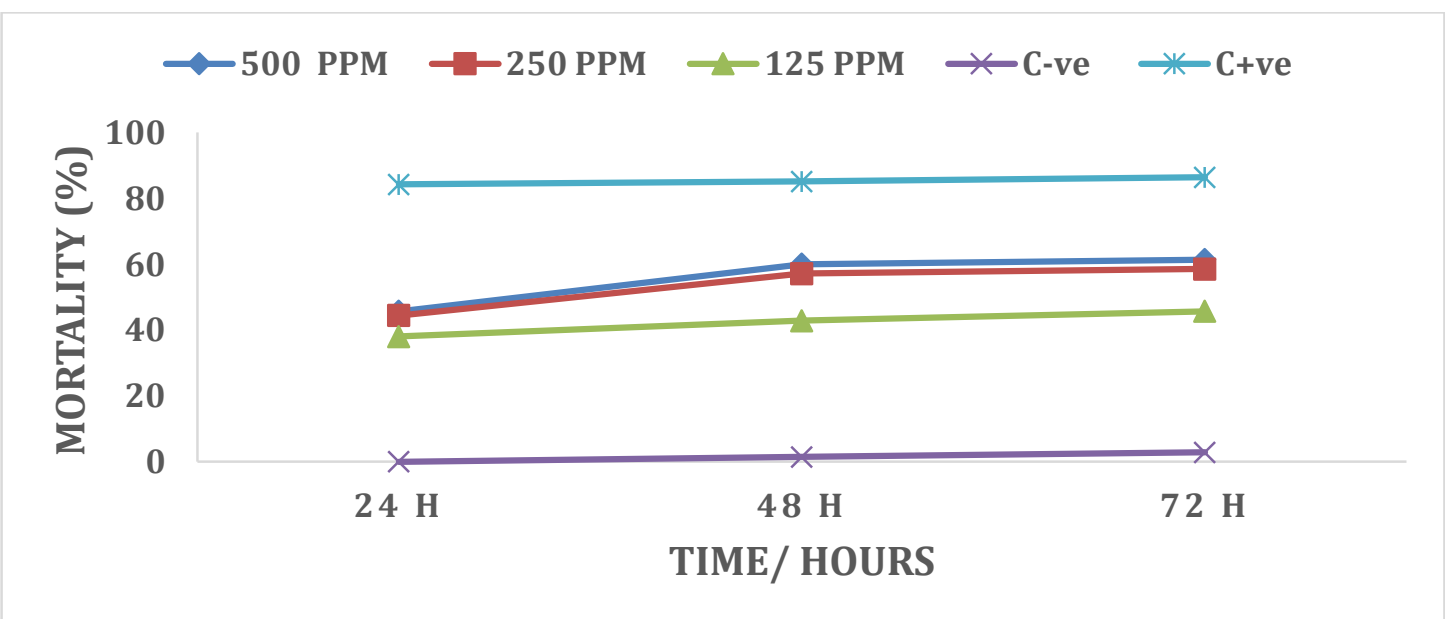

Fig. 3. In vitro activity of Cassia occidentalis ethanol extract against G. lamblia 


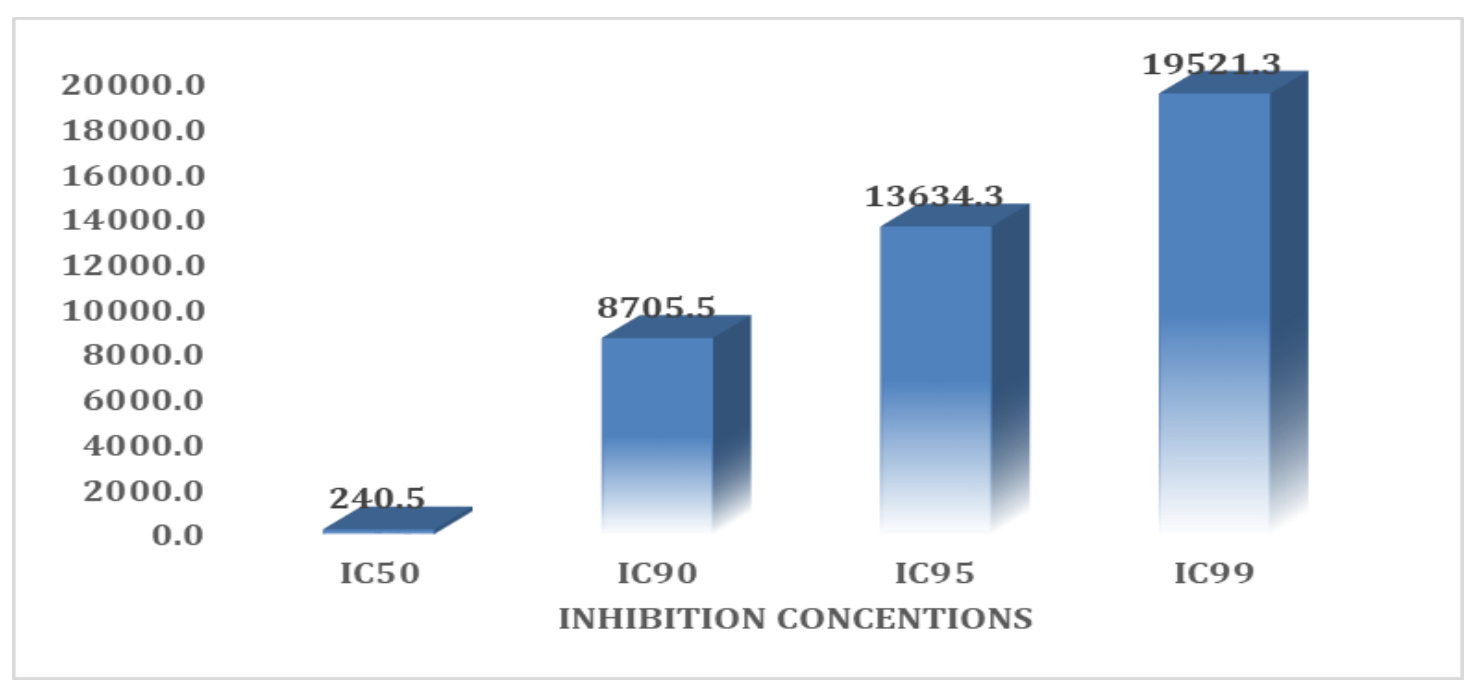

Fig. 4. Inhibition concentration (IC) Cassia occidentalis ethanol extract against G. lamblia

\subsection{Antioxidant Activity}

DPPH radical scavenging assay is the most common method used in the study of antioxidant activity of plant extracts Table 1. Cassia occidentalis crude extract showed moderate antioxidant activity (68.7 \pm 0.004$)$, While ethanolic extract of Abutilon pannosum showed lower activity (45 \pm 0.024$)$. The antioxidant activity may attribute to terpenoid content, as well as phenolic compounds (tannins) and (flavonoids) [13]. These results may be due to the moderate content of triterpenes, triterpenoids and fatty acids in the most ethanolic extract of Cassia occidentalis and low content of triterpenes in the ethanolic extract of Abutilon pannosum.
Table 1. Antioxidant activity of Abutilon pannosum and Cassia occidentalis crude extracts

\begin{tabular}{ll}
\hline Plants & Activity \%S $\pm / \mathbf{D}$ \\
\hline Abutilon pannosum & $45 \pm 0.024$ \\
Cassia occidentalis & $68.7 \pm 0.004$ \\
\hline
\end{tabular}

\subsection{Cytotoxicity}

Toxicity tests conducted using brine shrimp and normal cell lines (MTT) methods (Tables 2, 3). Ethanolic extracts of Abutilon pannosum and Cassia occidentalis were highly toxic in brine shrimp, whereas no toxicity was found when using MTT method.

Table 2. Cytotoxicity of plants extracts on brine shrimp

\begin{tabular}{|c|c|c|c|c|c|c|c|c|c|}
\hline \multirow[t]{3}{*}{ Samples } & \multirow{3}{*}{$\begin{array}{l}\text { Total Number of } \\
\text { shrimp }\end{array}$} & \multicolumn{6}{|c|}{ Concentrations $(\mu \mathrm{g} / \mathrm{ml})$} & \multirow{3}{*}{$\begin{array}{l}\text { ED } \\
(\mu \mathrm{g} / \mathrm{ml})\end{array}$} & \multirow{3}{*}{$\begin{array}{l}\text { The } \\
\text { degree } \\
\text { toxicity }\end{array}$} \\
\hline & & 1000 & 100 & 10 & 1000 & 100 & 10 & & \\
\hline & & \multicolumn{3}{|c|}{ Number of dead } & \multicolumn{3}{|c|}{ Number of survive } & & \\
\hline $\begin{array}{l}\text { Abutilon } \\
\text { pannosum }\end{array}$ & 10 & 10 & 03 & 02 & 00 & 07 & 08 & 100 & $\begin{array}{l}\text { High } \\
\text { toxic }\end{array}$ \\
\hline $\begin{array}{l}\text { Cassia } \\
\text { occidentalis }\end{array}$ & 10 & 10 & 01 & 00 & 00 & 09 & 10 & 165.9 & $\begin{array}{l}\text { High } \\
\text { toxic }\end{array}$ \\
\hline
\end{tabular}

Table 3. Cytotoxicity of plants extracts on normal cell lines (Vero cell line) as measured by the MTT assay

\begin{tabular}{|c|c|c|c|c|c|}
\hline \multirow[t]{3}{*}{ Name of Extracts } & \multicolumn{3}{|c|}{ Concentration $(\mu \mathrm{g} / \mathrm{ml})$} & \multirow{3}{*}{$\begin{array}{l}\mathrm{IC}_{50} \\
(\mu \mathrm{g} / \mathrm{ml})\end{array}$} & \multirow[t]{3}{*}{$\mathrm{IC}_{50}$} \\
\hline & \multicolumn{3}{|c|}{ Inhibition (\%) \pm SD } & & \\
\hline & 500 & 250 & 125 & & \\
\hline Abutilon pannosum & $59.43 \pm 0.01$ & $46.57 \pm 0.04$ & $38.86 \pm 0.02$ & 279.94 & $>100$ \\
\hline Cassia occidentalis & $66.28 \pm 0.06$ & $55.14 \pm 0.02$ & $44 \pm 0.04$ & 181.57 & $>100$ \\
\hline
\end{tabular}




\subsection{Gas Chromatography- Mass Spectrometry of Ethanolic Extract of Abutilon pannosum}

The results for GC-MS analysis of the ethanolic extract of Abutilon pannosum to the identification of several compounds. Totally 22 compounds were identified which have been listed in (Table 4). The chromatograph showed 22 peaks with 22 individual compounds (Fig. 3). The major constituents were identified in the ethanolic extract were N,N-Dimethylglycine (54.94\%), nHexadecanoic acid (8.90\%), Phytol (6.63\%), 1,3Propanediol, 2-(hydroxymethyl)-2-nitro (4.93\%) and many other compounds were identified as low level.

\subsection{Gas \\ Chromatography-Mass Spectrometry of Ethanolic Extract of Cassia occidentalis}

The ethanolic extract of Cassia occidentalis revealed the presence of 11 compounds as shown in (Table 5). The chromatogram showed 11 peaks with 11 individual compounds (Fig. 6). The main compounds in Cassia occidentalis were n-Hexadecanoic acid (25.79\%), 1,3Propanediol, 2-ethyl-2-(hydroxmethyl)-2-nitro (14.18\%), 9,12-Octadecadienoic acid (Z,Z)(13.47\%), Stigmasterol (11.73\%), 9,12,15Octadecatrienoic acid (Z,Z,Z)- (7.79\%), and many other compounds were identified as low level
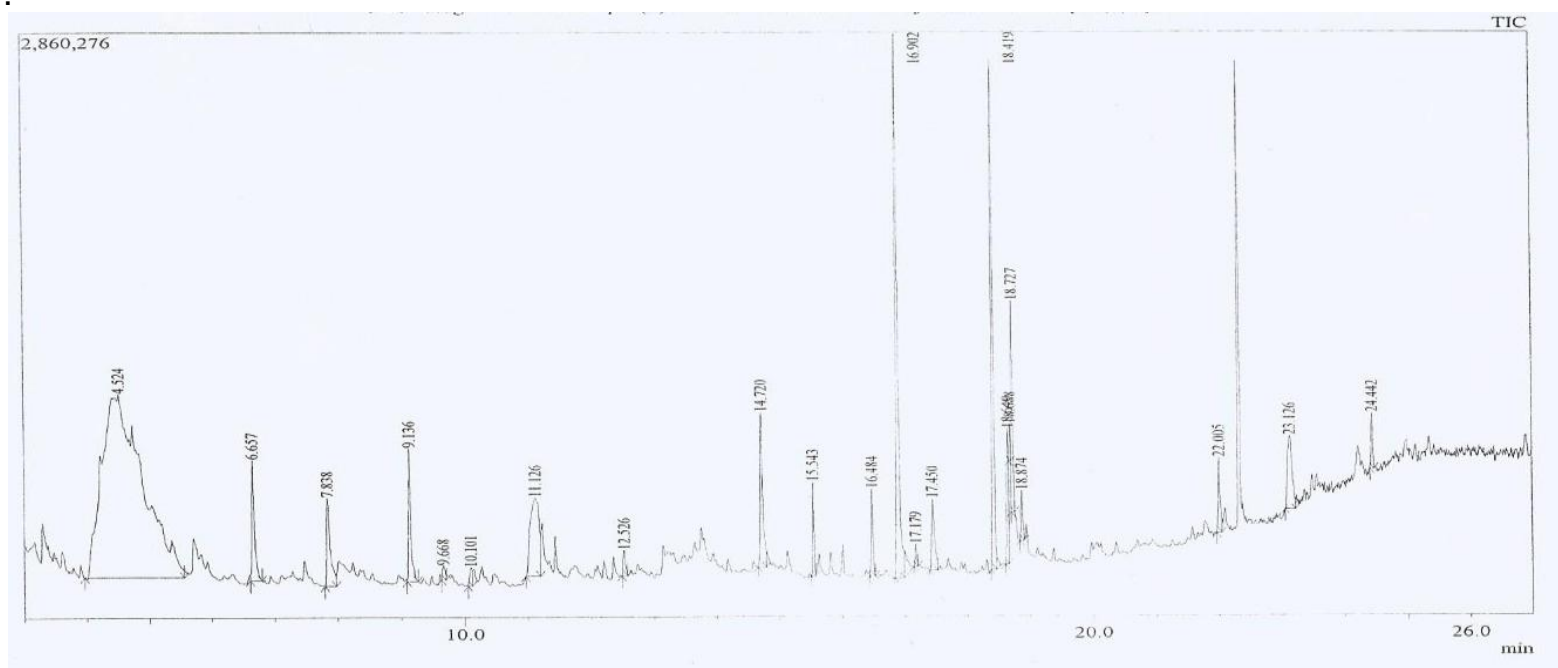

Fig. 5. GC-MS chromatogram of ethanolic extract of Abutilon pannosum

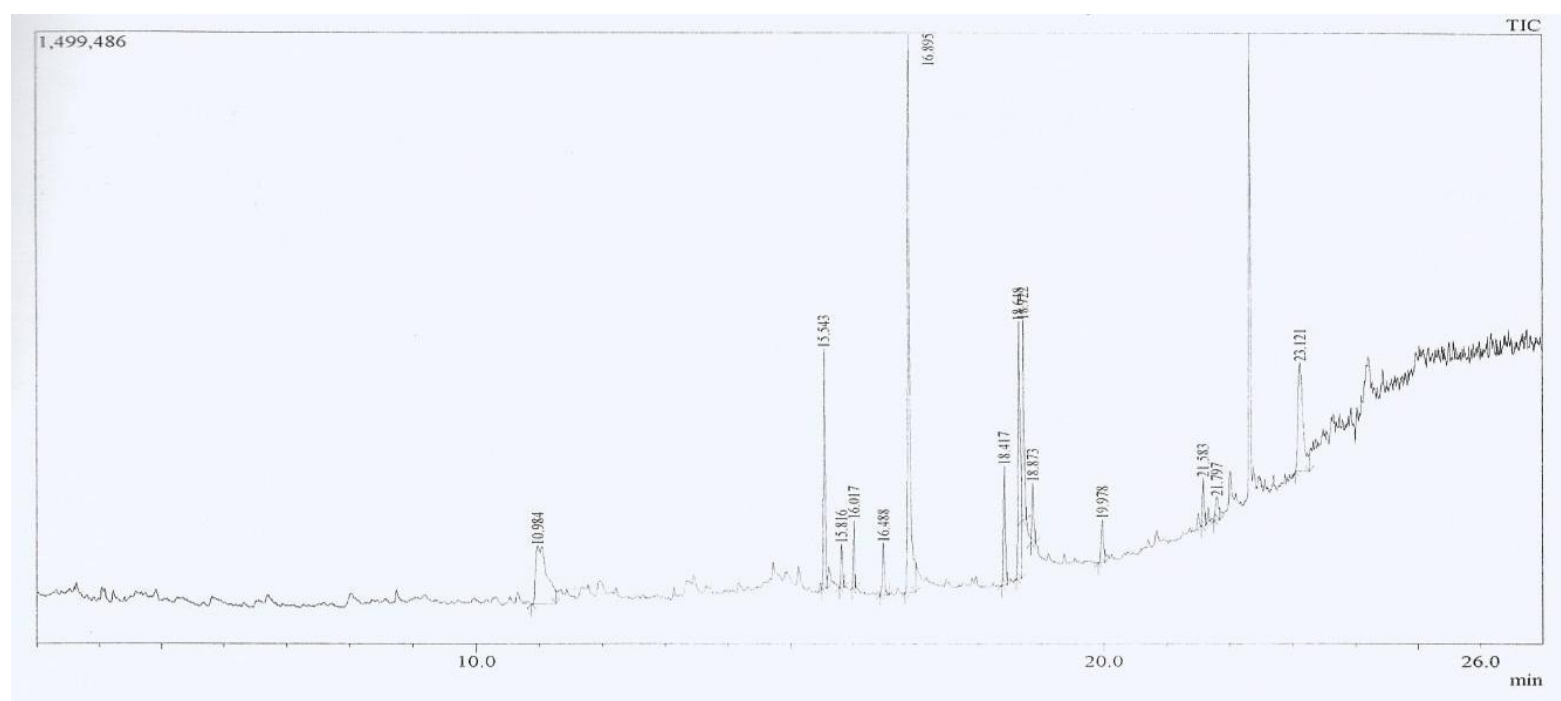

Fig. 6. GC-MS chromatogram of ethanolic extract of Cassia occidentalis 
Table 4. Phytocomponents identified in the ethanol extract of the aerial part of Abutilon pannosum by GC-MS peak report TIC

\begin{tabular}{|c|c|c|c|c|}
\hline Peak & $\begin{array}{l}\text { R. } \\
\text { Time }\end{array}$ & Area\% & Compounds Names & $\begin{array}{l}\text { Molecular } \\
\text { Formula }\end{array}$ \\
\hline 1 & 4.524 & 54.94 & N,N-Dimethylglycine & $\mathrm{C}_{4} \mathrm{H}_{9} \mathrm{NO}_{2}$ \\
\hline 2 & 6.657 & 2.33 & 4H-Pyran-4-one,2,3-dihydro-3,5-dihydroxy-6-methyl & $\mathrm{C}_{6} \mathrm{H}_{8} \mathrm{O}_{4}$ \\
\hline 3 & 7.838 & 2.48 & Benzofuran, 2,3-dihydro & $\mathrm{C}_{8} \mathrm{H}_{8} \mathrm{O}$ \\
\hline 4 & 9.136 & 2.18 & 2-Methoxy-4-vinylphenol & $\mathrm{C}_{9} \mathrm{H}_{10} \mathrm{O}_{2}$ \\
\hline 5 & 9.668 & 0.28 & Phenol, 2,6-dimethoxy & $\mathrm{C}_{8} \mathrm{H}_{10} \mathrm{O}_{3}$ \\
\hline 6 & 10.101 & 0.36 & DL-Proline, 5-oxo-,methyl ester & $\mathrm{C}_{6} \mathrm{H}_{9} \mathrm{NO}_{3}$ \\
\hline 7 & 11.126 & 4.93 & 1,3-Propanediol, 2-(hydroxymethyl)-2-nitro & $\mathrm{C}_{4} \mathrm{H}_{9} \mathrm{NO}_{5}$ \\
\hline 8 & 12.526 & 0.44 & 1,3-Isobenzofurandione, 4,5,6,7-tetrahydro-4,7-dimethyl & $\mathrm{C}_{8} \mathrm{H}_{8} \mathrm{O}_{3}$ \\
\hline 9 & 14.720 & 2.92 & Tetradecanoic acid & $\mathrm{C}_{14} \mathrm{H}_{28} \mathrm{O}_{2}$ \\
\hline 10 & 15.543 & 1.05 & 3,7,11,15-Tetramethyl-2-hexadecen-1-ol & $\mathrm{C}_{20} \mathrm{H}_{40} \mathrm{O}$ \\
\hline 11 & 16.484 & 1.18 & Lidocaine & $\mathrm{C}_{14} \mathrm{H}_{22} \mathrm{~N}_{2} \mathrm{O}$ \\
\hline 12 & 16.902 & 8.90 & n-Hexadecanoic acid & $\mathrm{C}_{16} \mathrm{H}_{32} \mathrm{O}_{2}$ \\
\hline 13 & 17.179 & 0.25 & Hexadecanoic acid, ethyl ester & $\mathrm{C}_{18} \mathrm{H}_{36} \mathrm{O}_{2}$ \\
\hline 14 & 17.450 & 1.51 & Benzenepropanoic acid, 2,5-dimethoxy & $\mathrm{C}_{11} \mathrm{H}_{14} \mathrm{O}_{4}$ \\
\hline 15 & 18.419 & 6.63 & Phytol & $\mathrm{C}_{20} \mathrm{H}_{40} \mathrm{O}$ \\
\hline 16 & 18.649 & 1.94 & 9,12-Octadecadienoic acid, (Z,Z) & $\mathrm{C}_{18} \mathrm{H}_{32} \mathrm{O}_{2}$ \\
\hline 17 & 18.688 & 0.30 & Oleic Acid & $\mathrm{C}_{18} \mathrm{H}_{34} \mathrm{O}_{2}$ \\
\hline 18 & 18.727 & 2.54 & 9,12,15-Octadecadienoic acid, $(Z, Z, Z)$ & $\mathrm{C}_{18} \mathrm{H}_{30} \mathrm{O}_{2}$ \\
\hline 19 & 18.874 & 0.62 & Octadecadienoic acid & $\mathrm{C}_{18} \mathrm{H}_{32} \mathrm{O}_{2}$ \\
\hline 20 & 22.005 & 1.11 & $\begin{array}{l}\text { Hexadecanoic acid, 2-hydroxy-1-(hydroxymethyl) ethyl } \\
\text { ester }\end{array}$ & $\mathrm{C}_{19} \mathrm{H}_{38} \mathrm{O}_{4}$ \\
\hline 21 & 23.126 & 2.47 & Stigmasterol & $\mathrm{C}_{29} \mathrm{H}_{48} \mathrm{O}$ \\
\hline 22 & 24.442 & 0.64 & Squalene & $\mathrm{C}_{30} \mathrm{H}_{50}$ \\
\hline
\end{tabular}

Table 5. Phytocomponents identified in the ethanol extract of the aerial part of Cassia occidentalis by GC-MS peak report TIC

\begin{tabular}{lllll}
\hline Peak & $\begin{array}{l}\text { R. } \\
\text { Time }\end{array}$ & Area\% & Compounds Names & $\begin{array}{l}\text { Molecular } \\
\text { Formula }\end{array}$ \\
\hline 1 & 10.984 & 14.18 & 1,3-Propanediol, 2-ethyl-2-(hydroxmethyl)-2-nitro & $\mathrm{C}_{6} \mathrm{H}_{14} \mathrm{O}_{3}$ \\
2 & 15.543 & 8.34 & 3,7,11,15-Tetramethyl-2-hexadeen-1-ol & $\mathrm{C}_{20} \mathrm{H}_{40} \mathrm{O}$ \\
3 & 15.816 & 1.61 & 9-Eicosyne & $\mathrm{C}_{20} \mathrm{H}_{38}$ \\
4 & 16.017 & 2.24 & Octadecene, 2-methyl- & $\mathrm{C}_{19} \mathrm{H}_{36}$ \\
5 & 16.488 & 2.29 & Lidocaine & $\mathrm{C}_{14} \mathrm{H}_{22} \mathrm{~N}_{2} \mathrm{O}$ \\
6 & 16.895 & 25.79 & n-Hexadecanoic acid & $\mathrm{C}_{16} \mathrm{H}_{32} \mathrm{O}_{2}$ \\
7 & 18.417 & 4.67 & Phytol & $\mathrm{C}_{20} \mathrm{H}_{40} \mathrm{O}$ \\
8 & 18.648 & 13.47 & $9,12-$-Octadecadienoic acid (Z,Z)- & $\mathrm{C}_{18} \mathrm{H}_{32} \mathrm{O}_{2}$ \\
9 & 18.722 & 7.79 & 9,12,15-Octadecatrienoic acid (Z,Z,Z)- & $\mathrm{C}_{18} \mathrm{H}_{30} \mathrm{O}_{2}$ \\
10 & 18.873 & 2.41 & Octadecanoic acid & $\mathrm{C}_{18} \mathrm{H}_{36} \mathrm{O}_{2}$ \\
11 & 19.978 & 2.16 & 2,6 Bis[2-(dimethylamino)ethoxy]pyridine & $\mathrm{C}_{13} \mathrm{H}_{23} \mathrm{~N}_{3} \mathrm{O}_{2}$ \\
12 & 21.583 & 1.73 & 3-Cyclopentylpropionic acid, 2-dimethylaminoethyl ester & $\mathrm{C}_{12} \mathrm{H}_{23} \mathrm{NO}_{2}$ \\
13 & 21.797 & 1.58 & 2-Ethylbutyric acid, eicosyl ester & $\mathrm{C}_{6} \mathrm{H}_{12} \mathrm{O}_{2}$ \\
14 & 23.121 & 11.73 & Stigmasterol & $\mathrm{C}_{29} \mathrm{H}_{48} \mathrm{O}$ \\
\hline
\end{tabular}

\section{CONCLUSION}

This study revealed the biological activity of Abutilon pannosum and Cassia occidentalis, where it showed Anti-giardia and antioxidant activities and was non-cytotoxic in the normal cell line. The chemical content of these plants has also been identified.

\section{ACKNOWLEDGEMENTS}

We would like to thank the Department of biology and biotechnology, Alneelain University for their valuable support. We are also thankful to the Department of Department of Microbiology, Faculty of pure and applied sciences for 
providing facilities for this work along with valuable guidance.

\section{COMPETING INTERESTS}

Authors have declared that no competing interests exist.

\section{REFERENCES}

1. Abdalla WE, Abdallah EM. Promising sudanese medicinal plants with antibacterial activity, Biological Forum An International Journal. 2016;8(1):299323.

2. Karar M, Rezk A, Abdalla T, Ebrahim A, Ullrich S, Kuhnert N. Antimicrobial, antiparasitic and antioxidant activities of medicinal plants from Sudan. Journal of Alternative and Complementary Medicine Health. 2017;2:555597.

3. Sen A, Batra A. Evaluation of antimicrobial activity of different solvent extracts of medicinal plant: Melia azedarach $L$. International Journal of Current Pharmaceutical Research. 2012;4(2):6773.

4. Aadesariya MK, Ram VR, Dave PN. Extraction, Isolation and Identification of Useful Phyto Constituents from Dichloromethane Leave Extract of Abutilon Pannosum and Grewia Tenax Using QTOF LC/MS. International Journal of Advanced Research in Chemical Science. 2017;4(10):1 - 14.

5. Arya V, Yadav S, Kumar S, Yadav J. Antimicrobial activity of Cassia occidentalis $L$ (leaf) against various human pathogenic microbes. Life Sciences and Medicine Research. 2010;9:e12.

6. Cedillo-Rivera R, Chávez B, González-Robles A, Tapia A, Yépez-Mulia $\mathrm{L}$. In vitro effect of nitazoxanide against Entamoeba histolytica, Giardia intestinalis and Trichomonas vaginalis trophozoites.
Journal of Eukaryotic Microbiology. 2002;49:201-208.

7. Arguello-García R, Cruz-Soto M, RomeroMontoya L, Ortega-Pierres G. Variability and variation in drug susceptibility among Giardia duodenalis isolates and clones exposed to 5-nitroimidazoles and benzimidazoles in vitro. Journal of Antimicrobial Chemotherapy. 2004;54:711721.

8. Eltayeb OM, Jobara MI, Mohamed MA, Elshikh AA, Masaad AM. In vitro evaluation of antimicrobial, antioxidant activities and phytochemical screening of Quercus infectoria (galls) used in traditional medicine. Current Research in Microbiology and Biotechnology. 2015;3(2):595-599.

9. Meyer B, Ferrigni N, Putnam J, Jacobsen L, Nichols DJ, Mclaughlin JL. Brine shrimp: A convenient general bioassay for active plant constituents. Planta medica. 1982;45:31-34.

10. Oladimeji H, Nia R, Essien E. In-vitro antimicrobial and brine-shrimp lethality potential of the leaves and stem of Calotropis procera (ait). African Journal of Biomedical Research. 2006;9(3):205 - 211.

11. Patel S, Gheewala N, Suthar A, Shah A. In-vitro cytotoxicity activity of Solanum nigrum extract against Hela cell line and Vero cell line. International journal of pharmacy and pharmaceutical sciences. 2009;1:38-46.

12. Kabbashi AS, Osman EE, Garbi MI, Ahmed IF, Saleh MS, Badri AM, Elshikh A A, Abuzeid N, Koko WS, Dahab MM. In vitro Antiprotozoal activities and cytotoxicity of selected Sudanese medicinal plants. International Journal of Biomedical Engineering and Clinical Science. 2017;3(2):6-13

13. Osman OAA, Abadi RSM, Ayoub SMH. Chemical constituents and antioxidant activity of some Sudanese medicinal plants. Journal of Pharmacognosy and Phytochemistry. 2018;7(6):1751-1755.

(C) 2021 Elshikh et al.; This is an Open Access article distributed under the terms of the Creative Commons Attribution License (http://creativecommons.org/licenses/by/4.0), which permits unrestricted use, distribution, and reproduction in any medium, provided the original work is properly cited.

Peer-review history:

The peer review history for this paper can be accessed here: https://www.sdiarticle4.com/review-history/61295 